\title{
DREAMS INTO REALITY: PRIVILEGED WOMEN AND POLITICS OF GENEROSITY
}

\author{
Ülle Tammemägi-Abuelnaga \\ Institute for Cultural Research, Tartu University, Estonia
}

\begin{abstract}
In the Egyptian capital, the privileged women turn to individual charity and their actions endorse social transformation on the field of education, expressing their political activity in a different form. Co-mixture of their wealth, local cultural particularities, in disrepair educational system and mistrust for governing body, which recurrently stifles meaningful women's empowerment, has led those females to seek a new path to power. Based on interviews, participant observation and guided conversations conducted in Cairo between 2015 and 2017, this study explores how women's daily social actions are transformed into political practices. In the context which demands performance and presence, ethical giving by women, as women in themselves, as mothers and as spouses, has become the vessel in which their political agency is carried out. Thus the privileged women of Cairo are subjects of this study and their acts of giving in everyday life are objects of this research. As a result, participants knowingly desist public political participation and use their advantaged position in the society informally to help to reduce poverty and enhance education through invisible individual philanthropic acts by assisting disadvantaged people to gain access to resources and thus drive a social change in Egypt. This occurrence contributes on reassessing agency in terms of Saba Mahmood's (2011) argument about "discounted agency" outside the usual forms and institutions of politics.
\end{abstract}

Keywords: Agency, Charity, Egypt, Women

\section{Introduction}

Since 2001, the women's freedom and rights in the Middle East have become a primary concern for the political and academic circles in the West, where frequently overstated interpretation of women's suffering and discrimination live. Traditionally, the Western feminist thought has shouldered the idea that women in the Middle East lack freedom, independence and are downtrodden by many affairs.

Contrary, in Egypt, women's activism has long rooted in the history of the social and political conditions and the Arab Uprising (2011) was only the latest in a long line of upheavals where women publicly played the significant role. Questions have been raised about the women's opportunities for political participation in public life by international organizations as well as by home-grown local feminist agencies. Liberal feminist ideals for freedom are related to a struggle to have equal rights and opportunities, where in Egypt, women's independence has acquired a very different status in reality, mostly due to the different socio-historical context and to the fragile relationship between the state and citizens.

Most of the research to date tends to focus on issues advocating for political empowerment of women in Egypt (Al-Ali 2000; El-Gousi 2016; Allam 2017), relationship between women and Islam (Badran 1993, Mittermaier 2014, El-Gousi 2016), and last but not least on the lower income households (Singerman 1996, 2007, Ghannam 2004) as well as on the impact of perceptions on women (Tammemagi-Abuelnaga, 2013; UN Women 2017). Our understanding of different forms of women's political participation concluded in number of previous and current studies still remains meager. Investigating how women of privilege convey political meaning to their everyday acts of giving and how these, often invisible acts of generosity, in return impact the schooling practice in Egypt, brings light upon women's indirect approach of being politically engaged. Thus there are some important areas where this study makes an original contribution to scholarship on generosity, education, and alternative forms of women's political participation. 
This paper will first give a concise background of research methodology and its participants' profile. It will then briefly examine the current situation in Egypt. The next section presents the findings of the fieldwork, focusing on the three key themes: daily life of privileged women, charity, and education; followed by the discussion. Finally, the conclusion gives a brief summary and critique of the findings, including implications of the findings for future research into this area. Due to the length constraints of this paper, it will not provide a comprehensive overview of current charity or political and educational systems in Egypt, they are addressed briefly and only the main points of data have been presented as deemed necessary.

\section{Methodology}

\section{Objectives}

The purpose of this paper is to present findings of one year and a half ethnographic fieldwork, to describe and interpret the political impact the privileged Egyptian women have on social policy transformation and on education through their everyday acts of charity. The research strives to understand in what ways elite women in Eastern Cairo influence social, and consequently political development, by devoting their time and money to enhance education and educating in Egypt. This account also expects to shed light on what kind of freedoms those women actually want or need and how they position themselves in respect to their socio-political identity.

\section{Participants}

The main aim of the research was to explore the real daily life of privileged women who have a good financial standing, are married and have children, who hold a college degree, can communicate in English and who work. These eligibility criteria for participants were chosen to limit external obstacles that would discourage public political participation in a general context. Secured financial standing hypothetically diminished concern for monetary needs and offered the potential capacity to enter politics. Marital status assured fulfilling social norms and having respectable status within the Egyptian society. The purpose of including women with children was two-fold: one to establish woman's respected social status due for having bared children, and two, an obligation of allocating time as mothers. The Higher educational background was necessary to establish participant as an informed and aware candidate for political office. Eligible women who match the selection criteria were aged between 30 and 39. Religion was not included in the selection criteria and both Christians and Muslims were represented. Pseudo-names were used for women instead of the real names to protect their privacy.

\section{Methods}

Researcher position of and to the group studied was distinctive: neither a visiting scholar nor anthropologist of home, but an observer who lives, works, and has a affinal relationship to the Egyptian society. These privileges contribute to researcher's place in the social system and thus social activities themselves become meaningful as they are not only communicative relations but actual social relations (Bourdieu 1977, p.1).

Using participant observation, open-ended and informal interviews and in-depth dialogs with 7 participants. In addition multiple information sources were used to complement the knowledge bank (interviews, observing, participating in activities related to research topics such as schools, charity, meetings, social events and other daily activities, articles, leaflets, advertisements, lessons, etc.) for more reliable results and analysis. Furthermore, a short survey was conducted including 33 women of the same selection criteria. Each interviewee was met in her natural settings chosen by her as an attempt to make her feel as comfortable as possible. Participants were informed about the purpose of the interview and ethical clearance was obtained. Part of the data was recorded in notes and journals, and other parts by using a digital recorder and then promptly transcribed. The particular limitations of given ethnographic data include a small number participants and their very specific conditions of selection criteria.

\section{Specific context of the case study}

The modern state of Egypt has gone through numerous transformations and adjustments of power struggles in the last (few) decade(s) in terms of economic, political, social and religious developments. Women's rights and political involvement in Egypt is a complex one like in many other countries in the Middle East and the North Africa (MENA) region. Historically, the milestones for women in the government legislation have been aimed at the legal empowerment of women including reforms in the Personal Status Law that deals mainly with individual rights regarding marriage, divorce, child custody and inheritance in the context of Islamic jurisprudence (Al-Sharmani 2008). Regrettably, the Egyptian government has often addressed women's political 
empowerment for the benefit of popular support of the regime or only due to Western pressure as it has sought to obtain legitimacy in the international arena and not because it is truly interested in women's empowerment (Younis 2007; Dawoud 2010). Many inequalities between men and women, in terms of power, are manifested in the opportunities to access and use resources, whether economic, social or cultural. Egyptian state has done a little to either help to include and integrate such opportunities for women or more frequently abandon those.

Although there has been slight social evolvement in Egypt on fields such as health care, education and women's employment in paid work, and modification in the constitution after the Arab Uprising granted that some further political rights to women, their wishes have stayed neglected under a chain of authoritarian rulers. Factually, there is a number of women's organizations and agencies, networks of non-governmental and governmental organizations concerned with women's empowerment and equal political participation who have worked in the framework of Western secular feminism agenda (Al-Ali, 2000). These NGO's have continuously lobbied for the gender equality in Egypt in respect to status of civil, social, political, economic developments and to stop violence against women (Komsan 2016). Recently however, these organizations have come under criticism and scrutiny, alongside the Egypt's federal government, for being not the representatives of real Egyptian women problems, relevant to their lives and difficulties. Instead, those NGO's have been said to reflect the views, desires and hopes of a small group of secularly minded, highly educated elite women whose wish is to be active publicly. Although privileged women interviewed in this study noted that the existence of such organizations is important, they have clearly distanced themselves from any women's rights groups. Thus looking at elite women's daily social life outside the framework of western notion of feminism, presents a perspective into their experience from their angle. It will illustrates the diversity of viewpoints represented within a community about social and political stances and show reasons particular women believe are behind their choices.

\section{Findings and Discussion}

In this study, women who were members of any political party or relevant organization were excluded. To begin to understand why individual women with means don't participate more actively in politics that takes place in the public sphere, the following main questions were addressed:

- How do they understand and define political participation?

- What are their incentives not to participate in public politics?

- How do they manage their daily schedule?

- Why and how is education important to them?

- How their individual actions make a difference in the society?

\section{Results}

The interviewees believed that as a concept it is important for women to be represented in public politics as they form half of the Egyptian population. They must have a role in the decision-making process, legislation and participate actively in making a difference, especially in regard to issues that would make a real difference for all women and the society as a whole.

"Women already participate in civil society and have roles in various NGOs and share in all other aspects of society. After 2011 revolution, their role proved to be even more pivotal and of great mobilizing force." (Mona, 39, Executive secretary in university)

Some participants expressed their belief that even though they agree about the prominence of women's part in the political arena, it is not worthy to be politically involved in Egypt (Graph 1).

"After the Egyptian revolution on the 25th January 2011, Egyptians became more positive about government and politics... most of us, including women, we became interested to follow and participate in politics. After years of being negative about parliament and the government. People [in the government] were not effective in political life! I hope this [revolution] will raise the awareness and give a chance in the near future to get things right. To make changes for right choices such as educational improvements and women rights and their participation in politics. To prioritize healthcare, child care and other urgent problems we have in our society." (Lamyaa 34, Pharmacist) 
Graph 1 Actual percentage of privileged women who expressed their interest to actively get involved in public politics (i.e. running for an office) [Women's interest in public political participation]

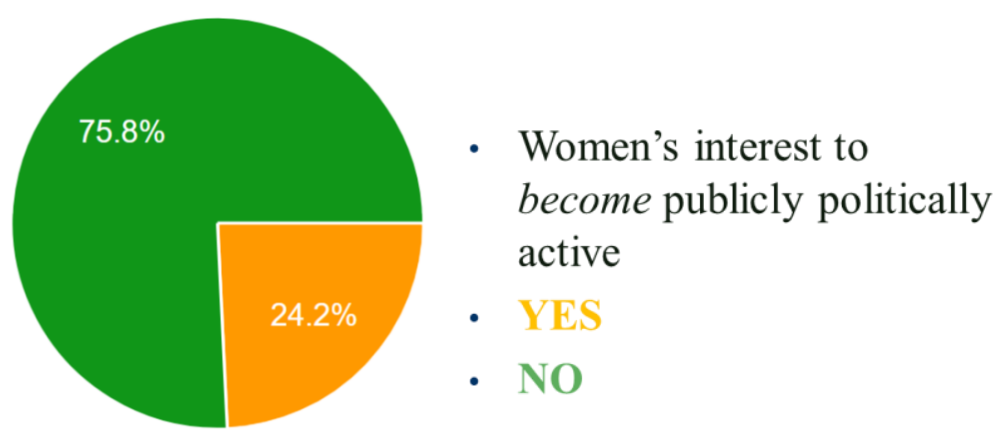

It was a general feeling that there are many qualified women but they are not holding the public political position. Approximately half of those questioned noted that they do follow political news and have always voted in elections. All of the participants believed that if they chose to , they could enter into the public political discourse, yet their decision not to, was an informed personal preference. Furthermore, the majority of elite women in study held a view that they would not like to join a political party or run for an office themselves, mainly because their input will not make any difference (Graph 2).

Graph 2 A number of issues have been identified as underlying reasons why elite women do not wish to participate in public politics. [Reasoning

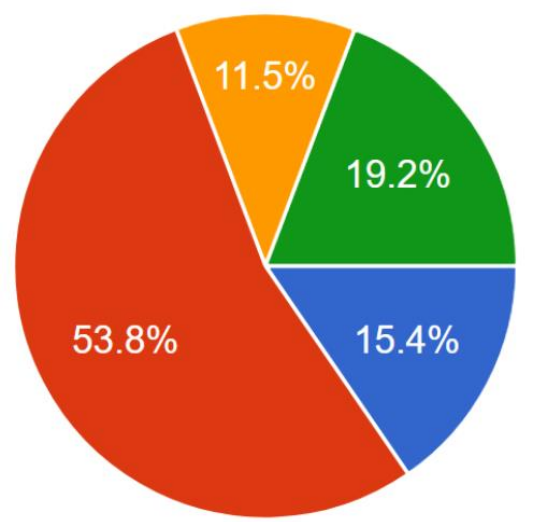

- $11.5 \%$ Not sure how

- $15.4 \%$ My in put makes no difference

- $19.2 \%$ Other (ways to make a contribution)

- $\mathbf{5 3 . 8} \%$ Not interested

"I guess most women here in Egypt and the Middle East are not interested in politics such as parliament and ministry. There was lots of corruption and bribery before the revolution. Many people in the government didn't care about society. We saw it with Mubarak and others at court after people took the regime down and money they had on their [bank] accounts. I think I didn't care about politics... it changed little for me and for my family, for Egyptian people.” (Hala, 38, founder and HR manager in private firm)

A number of issues were identified with a political system and the estranged relationship it has had with civil society. There was a sense of distrust among interviewees and lack of hope for the state government to advance the well-being of the nation. As one interviewee put it: "If we don't care about our people, who should care?" (Deena, 34, Bank customer service rep) A minority of women believed that their family (husband or father) wouldn't approve of them joining a political party due to either fear for woman's safety or because particular cultural norms they are obliged to follow. The most significant impediment for nearly all women was time. Time, as the informants affirmed, created the real difficulty for them to claim public space in politics other than lack of trust in so called state apparatus.

"As a working mother, I'm extremely busy. I have no time! For us in Egypt, we take care of many things in the family. We want better future for our children and for our country. I believe I can make a better change with education" (Maha, 35, professional development instructor) 
Over three-quarters of women indicated that between being a mother and spouse, they are also working women with a successful career that is meaningful to them. A majority responded felt their family and children were their number one priority and ensuring the good education for their offspring carries a priceless value.

"You know?! Egyptian education system and its quality have come so not affordable to so many people! It is turned into a sign of prestige. All these private schools, they have word 'international' in their title and believe it entitles them to charge huge amounts of money from parents without any consideration for the actual standards and curriculum. You know, I didn't want to put my daughter in one of those schools. My husband insisted. I wanted her to have a good education that also teaches things in Egyptian way" (Mariam, 33, Pedagogy consultant)

The cost of education was stated by all participants as a number one item in their family budget, triggered by the rising cost of quality education and a poor public educational system. More precisely, interviewed women deemed reforms in Egypt's education and healthcare system as an immediate necessity. (Graph 3). The data suggests, as the most unforeseen development, that elite women strategically embrace alternative political participation such as contributing their time, skills and assets to improve the access to and resources of education in Egypt for those less fortunate on socio-economic status.

"I try my best in everything I do; including politics. We need to be involved in every part of life. Sometimes we have our own way to make politics and it all depends on what politics means to you. I think being good mother and wife and volunteering to help others can have a political side to it". (Deena, 34, Bank customer service rep)

Graph 3 List of topics (in order of importance) that according to surveyed 33 privileged women and 7 interviewees in Eastern Cairo need immediate reforms. [Priorities to improve]

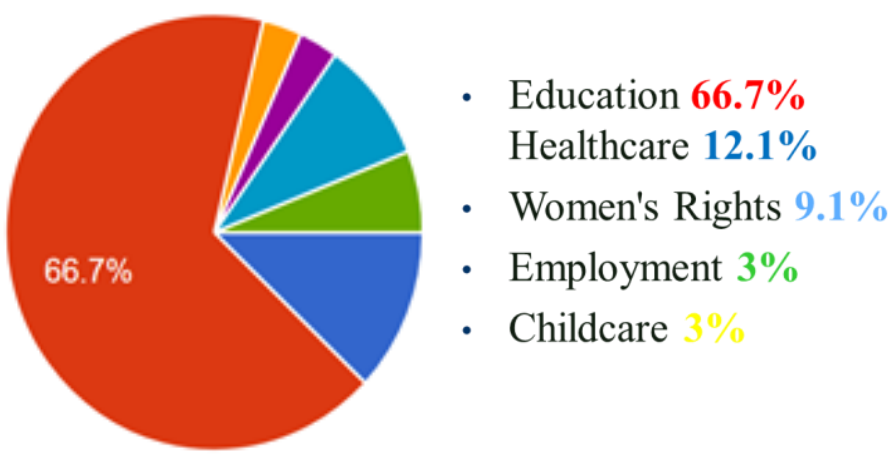

They do this by organizing fundraising events at their children's schools and volunteering their time and money to help to educate women and children or retrain teachers who work for the most part in public schools.

"In Arabic, there is a verse that says if you educate women, you educate the whole generation - so women are responsible for raising a new generation if they have a say they affect the whole community and affect its development." (Amany, 39, Private school librarian)

The single most remarkable observation to emerge from the data comparison was the absence of opposing views among participants (Christians and Muslims) regard to state role, individual charity, and the awareness of importance of education. The two themes of women's everyday acts of giving in terms of behavior and directing these giving's towards enhancement of education for Egyptians, recurred throughout the findings of the fieldwork. Some participants felt volunteering their time to teach various subjects to less privileged children is more effective than donating food and money, while others considered that the change has to start with retraining the parents and teachers by providing them with learning support and opportunities. Whilst a minority mentioned that they can influence their own family and larger kin only, all agreed that as women of privilege, it was their responsibility and moral duty to do what they can to help society's transformation along. Together these results provide important insights into the real life and thinking of privileged women, suggesting that there is an association between informal politics, individual women's intent to give, education and social transformation in Cairo. 


\section{Discussion}

The main objective of the research project was to examine Egyptian women and their interest - or lack of it - in policy-making and public political participation on different levels and prioritize underlying causes as described by informants to partake or withdraw from formal political actions. Findings of the ethnographic fieldwork discussed here about women from privileged backgrounds, who have renounced the public political participation and membership in the women's rights organizations, displays a shift from the traditional form of political engagement to a more innovative practice. As an alternative route towards power, these women use their advantaged position in the society to influence education by means of philanthropic acts to push for a social change. Their path to new forms of political power has grown out from a number of circumstantial conditions where women find themselves located.

\section{Unfulfilled promises}

First, Egyptians as a nation, have slowly grown apart with the trust they have in their government. If in Mubarak era citizens' doubt was contributed largely to the population's poorer classes, it had reached other social classes by the period of the post-Arab Uprising era, including many urban upper-class women in Eastern Cairo. The distrust and lack of transparency by the state government have significantly undermined the relationship Egyptian citizens have and attitudes they hold towards central state institution (Khalifa \& Olivera 2016). It is usually assumed that government will enhance citizens' trust in a state and consequently state would stand for the nations' well-being. According to one of the informant's statement:

"We feel we believe words. We have a hope in words. The government talks, but they never actually do [anything]. We in return talk and discuss amongst ourselves, listen and write about change and policy, but it never even materializes." (Hala, 38, founder and HR manager in private firm)

Restrictions under which people of Egypt lived during former president Hosni Mubarak's rule, allowed very limited political and civil liberties. Most of the populace learnt to function without the state support and became rather fearful victims of the state power and abuse. Unjust social and political structures that were challenged on January 25th revolution still continue to be in place today. Administration's inability to deliver tangible outcomes has driven women to lose their faith in the state interest of civil society's prosperity. In this context, political participation discussed by informants, bring to the surface not only the issues of women's political participation in Egypt but also the unequal opportunities based on social class and consequently gender.

Different women's accounts demonstrate one dimension of their underlying motives: it is not only whether it is possible for woman to participate in politics in this political climate, but also what kind of participation she prefers and values. Alternative notions of political activism of privileged women appear to be inspired precisely by the state failure to live up to given promises.

\section{Daily life \& Education}

Carrying out the business of everyday as working mothers and spouses, this group of women has grown impatient for promised changes to take place. Like low-income area women, elite women have daily schedules filled with appointments, errands, and activities. Though quite dissimilar in their nature, they still require usage of the same underdeveloped infrastructure in terms of streets and roads. Traffic jams that are common in Cairo, eat up hours from women's valuable time that they not only desire but need to spend with their children and family. As the challenge of time dominates the daily life, a lot of concern for these working parents has become built around schooling of children and education. In accordance, the findings observed in this study reflect those of the previous studies that have examined the effect of education on the Egyptian family. As described by Purinton \& Elsawy (2012), education in Egypt is very personal to most of the families and is seen as a tool for social mobility. Due to lack of governmental school reforms it is also the number one item on the family budget list for both private and public schools students although for different reasons.

Education is and has been an important engineer for Egyptian past, present and future. The ulama and Coptic clergy controlled customary schooling of the country's population up to 19th century through mosques and churches where boys learned to read and write, do basic arithmetic and memorize passages from the Quran or Bible (Lane 213, 536). Muhammed Ali and his grandson Ismail greatly expanded the schooling system by establishing the network of public schools, including the first school for the girls in 1873. During the British occupation (1882-1922) no advancements were made in the field of education, though a number of private schools were established that were largely affordable only for the wealthy. After the 1952 Revolution under 
Gamal Abdel Nasser, the public education was made free for all Egyptians, expanding future opportunities for boys and girls.

However, problems endured. From one side, the problem was the shortage of teachers and more recently, the quality of teachers teaching at public schools. The teaching career in the mid-20th century was seen as a not a prestigious job and those working in this field chose it as their last option. From the other side, over the past 200 years, Egypt has witnessed exponential growth in population, more than 30 folds from 3 million to more than 90 million, being marked as one of the top countries in population upsurge in the world in general, and in the Middle East in specific. The lack of professional development for educators and their low salaries, lack of capacity to accommodate a big number of incoming students and stagnated curriculum methodology, pushed the educational system to the edge. In present day, parents are left with little choice to provide stepping stone of quality schooling for their children other than private tutoring and for those who can afford new expensive private schools.

Co-mixture of mistrust for governing body and in disrepair educational system, as a second aspect of circumstantial conditions, has led participants to choose to invest their energy into something they can observe, influence and transform. Donating their time and money towards education assumes a different strategy for political participation that is invisible.

\section{Women \& Charity}

It is interesting to note that in six cases of this study, interviewees held that certain things in Egypt were their concern, especially in areas where the state had fallen short such as reduction of poverty and enhancement of education. They felt it to be their responsibility to do something about it. Prior studies that have noted the importance of charity in the Middle East are mainly dealing with the history of altruism on the organizational level, or charity and volunteerism that is religiously based. A new wave of Islamic activism to advance socioeconomic conditions of poorer classes in Cairo emerged in 1970' through the Muslim Brotherhood (MB) as a way of political resistance to the authoritarian regime and call to return to the basic principles of Islam. The Islamic revivalism in Egypt included women's movements such as the mosque movement or piety movement studied by Saba Mahmood and discussed in her book 'Politics of Piety' (2005). Mahmood analyses concepts of self, ethics and moral agency in the non-liberal movement of Muslim women in Cairo (where women attend to mosque lessons to gain religious knowledge about Islam in order to lead a pious life). She argues that 'agency' is too often seen as a resistance and challenge to social norms, and rather than seeing participants as victims we should see them as individuals engaged in ethical self-formation by their own (free) choice (Mahmood 2005). Agreeing with Mahmood, women's agency in the current study does not mean that by women choosing not to participate in public politics and practicing everyday acts of giving, women resist the social norms and the patriarchy. Rather participants' explanations demonstrate how participants see their own roles and position within the political and social context in Egypt; that is, being the "invisible agents" of change.

The majority of studies about the charity in the Middle East and more specifically in Egypt, focus on the relationship between society and religion and Islam and charity. Mona Atia (2008) has pointed out that Egypt, as a leading intellectual center of the Arab world, often sets trends in many areas of social life, including philanthropy (p.21). The author makes the connection between Islam and capitalism to learn the unanticipated relations between charity and the economy, the state, and religion in the transition from Mubarak-era Egypt. In an ethnographic account, Amira Mittermaier (2014) who studied Egypt's largest volunteer-driven charity organization Resala, found how compassion in Islam is imagined and mobilized to compel and justify giving in a particular context (p.519). Amy Singer (2013) has explored philanthropic practices in Islamic societies drawing on a wide variety of historical and contemporary sources dealing with aspects of Muslim practices of charitable giving. Signer's research, albeit historiographic, shows the association between charity, politics, and women, however, she does this within the Islamic framework (p.350).

The direction these scholarly studies pursue, complement the strong presence of giving in the Middle East in general, and in Egypt in particular yet in the context of Islam. Very little research is found linking charity to individual women outside of religious framework, and likewise, its connection to education and politics. Indeed, Egypt does have a long history of giving with deep roots in both the Muslim and Christian traditions; however, participants in my study contended that the culture of giving among Egyptians is not confined to religion and is commonly practiced among all citizens. Furthermore, they held views that generosity is not only religiously motivated and the giving practice in Egypt is generosity dating back to pre-Islamic, conceivably pre-Christian era: 
"Egypt people always are trying to do something good. Who can afford it, will try to give somebody something...you know. I think...people stopped hoping that government will do something for them and so they started to themselves...Egyptian culture, there is this thing about collective culture. I know. It is invisible in ways. It just happens...it's long tradition...I think it goes back to when people used to live in communities. In the small what they call it...I forgot the name, the tribes. So they used to have like outsiders and all the others are like a family. They help each other in many ways. And I think it has grown in a different way to the modern societies today. But still, there is this kind of ... like an invisible sense of community or related to feel like you should contribute... because you see them giving to you so you give back and it is a back and forth relationship in that sense. I think because the community has developed in that way since the early days on." (Mariam, 33, Pedagogy consultant)

Islamic and Christianity moral codes have been inherited from Antiquity, from Greek philosophers such as Aristoteles and Plato to name a few. According to more modern day philosopher Immanuel Kant (1996), an act can be ethical only if it is a conscious decision and not if it is performed unconsciously or for that matter, out of habit (p.67). It is encouraging to compare and place the behavior and actions of participants to the theoretical framework of Kant. For Kant, an action could only be ethical if it was a product of a reason (p.68). The reason for elite women's actions is their own feeling of responsibility for those in need and one can argue thus making their actions ethical irrespective of their political, socio-economic or religious positioning within society.

"I asked my husband, does your company do this social responsibility program at your work? I said, my girlfriend, told me that there are lots of public school teachers who want to attend a new program at the private university to get a diploma in teaching. But you know... it's too expensive for them! You know that the quality of education in Egypt is not good ... so I asking him [husband] to make a proposal to the committee to offer a scholarship for some teachers from public school as company's social responsibility. Well... Finally after two years, he [husband] came home said they just finalized the agreement with the university! I felt very happy! We have to ask, how can we help... The situation is not nice for many people" (Maha, 35, professional development instructor)

The individual actions of privileged women in this study can be seen as not moral codes imposed upon them by someone else, like the state or religious institution, but are rather formed within themselves as genuine acts of personal dignity. Women believed that what they do today as women themselves or as mothers and spouses will affect the society, including their children and grandchildren in the future. Hence it could conceivably hypothesize that rather than the accustomed way of partaking in the political amphitheater and women's rights organizations, the upper-class women in Eastern Cairo become agents of social change through the medium of charity advocating in private, yet in political terms, for those living in different economic and social circumstances.

\section{Conclusion}

The aim of this study was to discuss the reasons why Egyptian privileged women choose to pass up the opportunity to publicly engage in politics and find alternatively powerful ways to make a difference. These findings suggest that the shortage of women in public politics is not only produced by inequality requiring international involvement, nor religiously grounded or hindered by patriarchal culture often ascribed to be prevalent in Egypt, but rather women's participation in politics is invisible and is so, by informed personal choice.

This research has also established that women's political contribution and self-determination takes place through informal corridors of charity towards education. As argued and agreed by the participants - change is needed in educational system that would include everyone regardless of their social class and gender. Great importance must be placed on elite women's own agency as it is through their everyday acts of (ethical) giving where actual transformation happens. Women as individuals in the civil society can have a strong influence on remodeling social policy and improving educational outcomes for the benefit of all. Concurrently, participants' individual acts of giving, open the way to a new political participation that is masked and difficult to detect. Current study by Amy Singer (2013) debates the invisible nature of individual charity performed by women. Popularity of such approach seems to be in rise among elite women's relations and private circles in Egypt where political participation and agency defy their usual methods.

The most important limitation of this study lies within its strength - it is an ethnographic account that offers in depth understanding but also represents only part of the picture. It is recommended that further research is undertaken to better understand the motivations behind the women's generosity and giving practices. A greater 
focus on the issue of concealed political participation as well as unseen charity is an intriguing one which could be usefully explored in further research.

\section{References}

AL-ALI, N.S. (2000) Secularism, Gender and the State in the Middle East the Egyptian Women's Movement. New York: Cambridge University Press.

ALlAM, N. (2017) Panel Discussion, "Hope and Disappointment in Politics: Women and the Egyptian Uprising," organized AUC Forum at The American University in Cairo.

AL-SHARMANI, M. (2008). Recent Reforms in Personal Status Laws and Women's Empowerment: Family Courts in Egypt. The American University in Cairo and Pathways of Women's Empowerment, September.

ATIS, M. (2008) From Charity to Social Change: Trends in Arab Philanthropy. Cairo: AUC Press.

BADRAN, M. (1993) Feminists Islam and Nation: Gender and the Making of Modern Egypt. Cairo: American University Press.

BOURDIEU, P. (1977). Outline of a Theory of Practice. Cambridge: Cambridge Univ. Press.

DAWOUD, A. (2010). Utilizing mass media in the political empowerment of Egyptian women. Ph.D. dissertation, University of Westminister.

EL-GOUSI, H. (2016). Women's Rights in Authoritarian Egypt: Negotiating Between Islam and Politics. I.B. Tauris, Sew ed.

GHANNAM, F \& SHOLKAMY, H. (2004) Quest for Beauty Globalization, Identity and the Production of Gendered Bodies in Low-income Cairo. In Health and Identity in Egypt, (43-63)

KANT,I. (1996) The Metaphysics of Morals. In Mary J. Gregor Editor \& (Trans.), Practical Philosophy: The Cambridge Edition of the Works of Immanuel Kant, (67-68).

KOMSAN, N.A. (2016) 2016: The Egyptian Woman Important Steps \& Big Challenges. Women's Status Report Summary. ECWR.

MAHMOOD, S. (2005,2011). Politics of Piety: The Islamic Revival and the Feminist Subject. Princeton: Princeton University Press.

MITTERMAIER, A. (2014), Beyond compassion: Islamic voluntarism in Egypt. American Ethnologist, 41: 518-531. doi:10.1111/amet.12092

OLIVER DE,F. \& KHALIFA,M.(2016) The Egyptian Civil Society Organisations Role in Public Policymaking Process: Lessons from the Brazilian Experience. Public Policy and Administration Research. Vol.6. No 11 .

PURINTON,T \& ELSAWY, A. (2014). School Reform in the Middle East: Educational Researchers Adapting to the Arab Spring. In Enrique Mendizabal (Ed.), Communicating Complex Ideas Translating research into practical social and policy changes.(pp. 57-77)

SINGER, A. (2013) “Giving Practices in Islamic Societies.” Social Research 80.2 Summer: 341-358

SINGERMAN,D. (1996) Development, Change, and Gender in Cairo A View From the Household. Indianapolis: Indiana University Press.

SINGERMAN, D. (2007) The economic imperatives of marriage: Emerging practices and identities among youth in the Middle East. Washington, DC: Wolfensohn Center for Development.

TAMMEMAGI-ABUELNAGA,Ü. (2013). How Women's Participation in Politics is Perceived by Egyptians. Rabatuluke: Ethnology and Folklore Conference "Young Voices", University of Tartu, Estonia, April 27.-28., 2011.

UN Sustainable Development. (2017) Goals \& 2030 Agenda for Sustainable Development. https://sustainabledevelopment.un.org/post2015/transformingourworld

UN Women. El Feki, S., Heilman, B. and Barker, G., Eds. (2017) Understanding Masculinities: Results from the International Men and Gender Equality Survey (IMAGES) - Middle East and North Africa. Cairo and Washington, D.C.: UN Women and Promundo-US.

YOUNIS, M. (2007). Daughters of the Nile: The Evolution of Feminism in Egypt. Washington and Lee University Journal of Civil Rights and Social Justice, 13 Spring, p. 463. 